\title{
IMAGE IS INDEED EVERYTHING: AN ANALYSIS OF How AMERICANS VIEW LEADING COMPANIES TODAY ON THE SEVEN DIMENSIONS OF CORPORATE REPUTATION
}

\author{
David C. Wyld \\ Department of Management \& Business Administration, Southeastern Louisiana \\ University, Hammond, Louisiana, USA
}

\begin{abstract}
In today's economy, a substantial part of the value of a consumer-facing company is tied-up in the value of its corporate image and its brand. As such, major companies today have both a great opportunity and a significant challenge at hand in managing their corporate reputations. In recent years, we have seen numerous instances of how the public perception of companies - and their brands - can be either positively or negatively impacted almost overnight by a wide range of events, social media, and more. As such, "reputational risk" is - and will continue to be - a significant managerial concern. In this study, we explore recent survey data on how the American public regards leading companies today in regard to their reputations. Using data from a major national consumer survey, we examine the seven dimensions of corporate reputation and assess how the public views the "best" and "worst" companies today on each reputational aspect. The article concludes with a look at the managerial implications of the present research and a look ahead to how further research could both deepen our understanding of consumer perceptions of corporate reputation and connect the reputation construct to actual corporate performance.
\end{abstract}

\section{KEYWORDS}

Business, Strategy, Reputation, Brand Value, Branding, Marketing, Consumer Behavior

\section{INTRODUCTION}

"Image is everything..."

---- Andre Agassi

In 1989, these 3 words entered the American cultural and business lexicon forever. Andre Agassi, then a young, 19-year oldtennis sensation, uttered them - scripted - in a television commercial for Canon cameras [1]. The 3 words that drove this ad campaign became much more than a tagline to sell cameras and even went beyond Agassi, as they became not just iconic, but an idea. For good or for bad, we have entered into a period of history where our image, our brand - personally or collectively as a company - is wrapped-up in a complex, individualized consumer perception of what we are, what we do, what we believe, etc. In other word today, our image - and our reputation - are indeed everything in the modern age.

And both marketing and psychology research has shown that consumers will gravitate towards, or alternatively, consciously avoid buying specific brands of products or services from companies based on their perception of that company's image and reputation. In short, the science has shown that "we make brand purchase decisions based on the associations and feelings as opposed to the 
facts and stats" (n.p.) [2]. And since our individual consumer perceptions become reality for companies and their brands, today, more than ever, image is everything for consumer-facing firms.

Time and time again, we have seen that corporate branding and brand management matters greatly in the success or failure of entire companies [3]. Companies have succeeded over time due to the strength of their brands and their reputation, as evidenced by Ford and General Motors' longstanding dominance in American car manufacturing, building brands that command both customer loyalty and drive a "brand premium" for their products [4]. Likewise, when a crisis hits a company, such as the criminal Tylenol poisonings of the 1980's that impacted a major product for Johnson \& Johnson, many experts over the years have pointed to the strength of both the corporate (Johnson \& Johnson) and the product (Tylenol) brand and the company's good reputation as being the key factors in how the firm overcame the crisis [5]. On the flip side, we have seen companies' brands and reputations, along with their sales and financial results, take major hits when they respond poorly to a crisis. From BP's inept reaction to its major oil spill in the Gulf of Mexico over a decade ago [6] to today's controversy with Toyota contributing to Republican Congresspeople tied to the Insurrection at the United States Capitol in January 2021 that provoked a firestorm on social media [7], large companies can suddenly see very real damage to their brands, their reputations, and their finances that can be quite difficult to reverse. This is the concept of "reputational risk," defined as "the potential for negative publicity, public perception or uncontrollable events to have an adverse impact on a company's reputation, thereby affecting its revenue" (n.p.) [8], which is an ever-present reality for companies of all sizes today.

And so that is why there is such an interest today - and why the stakes are so high for companies all across the board - for corporate management to build and maintain a positive image for the company and its products in an era when yes, more than ever, image is indeed everything. Indeed, much of the investment companies make today in areas such as public relations, community involvement, and corporate image-focused advertising can be attributed to management strategically trying to maintain and to enhance, if possible, the image of the firm and its brands in the minds of consumers. For example, we have seen that companies can build their brand perceptions in the minds of consumers based upon doing "good works," whether at the local level like Chick-fil-A (donating food to local charities) [9], Subaru (putting an emphasis on the environment) [10], and both Southwest Airlines [11] and McDonald's [12] for their efforts to transport and house families near their hospitalized children in major metropolitan areas.

And yes, there is a bottom-line - or rather, a balance sheet issue to all of this as well. It might sound trite or even trivial to say that a company's reputation is its greatest asset. However, in truth, it really can be just as valuable as almost any tangible category of assets taken together that a firm may actually own. That is because all companies "own" something very intangible, their brand - and specifically, the goodwill that it holds for the company. Goodwill is not just an accounting concept, defined as "a key intangible asset that represents the portion of the business value that cannot be assigned to other business assets" (n.p.) [13], even if it is something of a "black box" calculation in many instances [14].

Yet, the intersection of goodwill and reputation is a key strategic imperative today. A company's reputation is a key component in valuing corporate goodwill, and this is because it has very real value to the company, as it is critical to maintaining ties with its customers, its employees, its value chain partners, and its wider communities. Yes, in short, image is indeed everything!

And that is the motivation behind this research. In order for companies to survive and thrive today, it is vital that they proactively seek to manage their corporate reputation in an increasingly 
International Journal of Managing Public Sector Information and Communication Technologies (IJMPICT) Vol. 12, No.3, September 2021

turbulent, volatile, and even fickle marketplace today. In one instant, executives can make or break the reputations of their company and themselves in the minds of the public, and in doing so, they can dramatically impact the fortunes of their firm and everyone associated with it. This research serves to help both management practitioners and researchers to better comprehend how - and why - consumers perceive the images of companies today as they do - both for good and for bad. In doing so, it is hoped that we can better understand the factors that go into making up a company's reputation and then be able to guide management as to how to more effectively manage the image of their firm in the public mind today.

\section{The Present Study}

In this article, we will examine the importance of corporate reputation today. We will make use of data from the latest rendition of an annual survey conducted jointly by Axios and The Harris Poll. This corporate reputation research has been conducted each year since 1999. The current year's version of the survey, the 2021 Axios/Harris Poll 100 [15], was conducted in April 2021 and released mid-year. The survey encompassed the views of a nationwide sample of over 42,000 Americans, seeking out their views on companies and their reputations.

The survey was conducted in two parts. First, between December 2020 and January 2021, the Axios/Harris Poll researchers asked over 6,000 survey participants to name four companies that immediately came to mind, specifically the two that they believed, from their perspective, had the best corporate reputations today and alternatively, the two that they felt had the worst reputations [16]. The goal of this part of the survey, according to Axios [17], was to gauge the "public's topof-mind awareness of companies that either excel or falter in society" (n.p.). The list of companies named in this initial survey was then pared down to the 100 most commonly mentioned - both positively and negatively - firms (and if a participant named a brand or subsidiary of a larger company, that firm was counted as being named directly by the respondent). These most frequently named corporations became both a list themselves, being deemed by Axios and the Harris Poll as the "100 Most Visible Companies in America" (see Table 1 - The 50 Most Visible Companies from the Axios Harris Poll 100), and the focus of a second round of polling.

Table 1 - The 50 Most Visible Companies from the Axios Harris Poll 100

\begin{tabular}{|l|l|l|l|}
\hline Visibility Rank & Company & Visibility Rank & Company \\
\hline 1 & Amazon.com & 26 & Best Buy \\
\hline 2 & Walmart & 27 & Toyota Motor Corporation \\
\hline 3 & Apple & 28 & Bank of America \\
\hline 4 & Facebook & 29 & Yum! Brands \\
\hline 5 & Google & 30 & Lowe's \\
\hline 6 & Target & 31 & ExxonMobil \\
\hline 7 & Microsoft & 32 & eBay \\
\hline 8 & Wells Fargo \& Company & 33 & Starbucks Corporation \\
\hline 9 & Nike & 34 & The Walt Disney Company \\
\hline 10 & McDonald's & 35 & GameStop \\
\hline 11 & Chick-fil-A & 36 & Publix Supermarkets \\
\hline 12 & Sears Holdings Corporation & 37 & The Kroger Company \\
\hline
\end{tabular}


International Journal of Managing Public Sector Information and Communication Technologies (IJMPICT) Vol. 12, No.3, September 2021

\begin{tabular}{|l|l|l|l|}
\hline 13 & AT\&T & 38 & Hobby Lobby \\
\hline 14 & Ford Motor Company & 39 & General Electric \\
\hline 15 & Twitter & 40 & IBM \\
\hline 16 & Costco & 41 & Sony \\
\hline 17 & Samsung & 42 & Macy's \\
\hline 18 & Tesla Motors & 43 & Fox Corporation \\
\hline 19 & Comcast & 44 & Johnson \& Johnson \\
\hline 20 & T-Mobile & 45 & Burger King \\
\hline 21 & Verizon Communications & 46 & Dollar General \\
\hline 22 & The Trump Organization & 47 & Netflix \\
\hline 23 & The Coca-Cola Company & 48 & PepsiCo \\
\hline 24 & General Motors & 49 & Kohl's \\
\hline 25 & The Home Depot & 50 & Robinhood \\
\hline
\end{tabular}

Source Data: The Harris Poll, 2021 Axios Harris Poll 100.

In the next step of the research, a second, completely different survey, representative of the American public as a whole, was conducted to gauge respondents' views on specific elements of corporate reputation. The Harris Poll has identified 7 specific dimensions that make-up a company's reputation, and survey participants were asked to respond to these questions to assess their perception of each aspect of corporate reputation:

1. Trust - "Is this a company I trust?"

2. Ethics - "Does this company maintain high ethical standards?"

3. Citizenship - "Does this company share my values and support good causes?"

4. Culture - "Is this a good company to work for?"

5. Products and Services - "Does this company develop innovative products and services that I want and value?"

6. Vision - "Does this company have a clear vision for the future?"

7. Growth - "Is this a growing company?" [15].

In essence, the survey participants were being asked for their perceptions of each company on these 7 aspects of corporate reputation, which centered around 3 specific areas:

1. Trust (Trust)

2. Character (Ethics, Citizenship, and Culture)

3. Trajectory (Products and Services, Growth, and Vision) [15].

In April 2020, over 42,000 Americans participated in this second round of the Axios/Harris Poll corporate reputation research, with each participant being asked to rate two of 100 the most visible companies that they were familiar with on the 8 dimensions of reputation. The responses were tabulated and each company received an indexed score between 0 and 100 on each of the 7 reputational dimensions. Taken together, these 7 scores make-up a firm's "RQ®" or "Reputation Quotient," which represents a holistic, consumer-level impression of a company's reputation [18]. The firms were then ranked based on their composite RQ Score, and that list, The Axios Harris Poll 100, represents the ranking of the most prominent American companies based on their perceived reputation among the American public. The top 10 rated corporations, along with their RQ Scores, are shown in Table 2 (The Top 10 Ranked Companies in the 2021 Axios Harris Poll 
International Journal of Managing Public Sector Information and Communication Technologies (IJMPICT) Vol. 12, No.3, September 2021

100). These firms were perceived by the general public to have the best corporate reputations. Conversely, on the other end of the spectrum, the 10 lowest rated companies, those with the worst perceived corporate reputations among the 100 most visible companies, are shown in Table 3 (The Lowest 10 Ranked Companies in the 2021 Axios Harris Poll 100).

Table 2 - The Top 10 Ranked Companies in the 2021 Axios Harris Poll 100

\begin{tabular}{|l|l|l|}
\hline Rank & Company & RQ Score \\
\hline 1 & Patagonia & 82.7 \\
\hline 2 & Honda Motor Company & 81.6 \\
\hline 3 & Moderna & 81.3 \\
\hline 4 & Chick-fil-A & 81.1 \\
\hline 5 & SpaceX & 81.1 \\
\hline 6 & Chewy & 80.9 \\
\hline 7 & Pfizer & 80.2 \\
\hline 8 & Tesla Motors & 80.2 \\
\hline 9 & Costco & 80.1 \\
\hline 10 & Amazon.com & 80 \\
\hline
\end{tabular}

Source Data: The Harris Poll, 2021 Axios Harris Poll 100.

Note: Guide to All RQ Scores and Individual Corporate Dimensions of Reputation Scores:

- Excellent: 80 \&Above;

- Very Good: 75-79;

- Good: 70-74;

- Fair: 65-69:

- Poor: 55-64;

- Very Poor: 50-54;

- Critical: Below 50.

Table 3 - The Lowest 10 Ranked Companies in the 2021 Axios Harris Poll 100

\begin{tabular}{|l|l|l|}
\hline Rank & Company & RQ Score \\
\hline 100 & The Trump Organization & 56.9 \\
\hline 99 & Fox Corporation & 59.2 \\
\hline 98 & Facebook & 60 \\
\hline 97 & Wish.com & 60.7 \\
\hline 96 & Sears Holdings Corporation & 61.2 \\
\hline 95 & Wells Fargo \& Company & 63 \\
\hline 94 & TikTok & 63 \\
\hline 93 & Twitter & 63.4 \\
\hline 92 & Comcast & 65.8 \\
\hline 91 & My Pillow & 66 \\
\hline
\end{tabular}

Source Data: The Harris Poll, 2021 Axios Harris Poll 100. 
As one can see when viewing these results, there is quite interestingly not an absolute correlation between a company's visibility (its familiarity with consumers) and its reputation. For instance, a number of the top ranked firms in terms of corporate reputation, including companies such as Patagonia (first in reputation, 83rd in visibility), the Honda Motor Company (second in reputation, 75th in visibility), and Moderna (third in reputation, 95th in visibility), are far less "top-of-mind" to consumers today. Conversely, Amazon, the most visible company today, is ranked tenth in corporate reputation by Americans. Further, a company like SpaceX, which is ranked fifth in terms of corporate reputation, is only the 90th ranked company in terms of visibility today. The company with the closest correlation to be found between its reputation and visibility is Chick-fil-A, which in 2021 was ranked fourth in reputation and eleventh in visibility by Americans. Thus, there is much to be done in terms of analyzing the Axios/Harris Poll data indepth to explore the relationship - both from a statistical and more importantly from a managerial perspective - between a firm's reputation and its visibility in the minds of consumers, that is well beyond the scope of this research.

In the present study, making use of the data provided by the Axios/Harris Poll researchers, we will look at the 7 aspects that make up corporate reputation. We will present the findings in regard to the "best" and "worst" companies on each reputational dimension. We conclude the article with a look at the implications of the present research for corporate management and a look at how future research could provide an even more in-depth look at the components that make up a company's reputation - and more importantly - the perception of such by consumers.

\section{Results}

In this section, we will explore the findings from this major national survey in regard to the 7 dimensions that comprise corporate reputation from the Axios/Harris Poll data. We will examine the results in regard to each reputational aspect, presenting both the "best" and "worst" regarded companies today. We will then discuss the findings regarding each dimension of corporate reputation.

\subsection{Dimension 1: Trust}

For the trust dimension, the survey participants were asked "Is this a company I trust?" The top ranked firms on this important aspect of corporate reputation are listed in Table 4 (The Most Trusted Companies in America for 2021), while the lowest rated companies are shown in Table 5 (The Least Trusted Companies in America for 2021). As can be seen in the two lists, the 3 most trusted corporate brands in America belong to Chewy, Chick-fil-A, and Patagonia, while on the flip side, the 3 least trusted companies today are Facebook, The Trump Organization, and the Fox Corporation.

Table 4: The Most Trusted Companies in America for 2021

\begin{tabular}{|l|l|l|}
\hline Rank & Company & Trust Score (Index=100) \\
\hline 1 & Chewy & 82.7 \\
\hline 2 & Chick-fil-A & 82 \\
\hline 3 & Patagonia & 81.9 \\
\hline 4 & Costco & 81.5 \\
\hline 5 & Honda Motor Company & 81.1 \\
\hline 6 & Amazon.com & 80.8 \\
\hline
\end{tabular}


International Journal of Managing Public Sector Information and Communication Technologies (IJMPICT) Vol. 12, No.3, September 2021

\begin{tabular}{|l|l|l|}
\hline 7 & IKEA & 80.6 \\
\hline 8 & CVS (CVS Health) & 80.4 \\
\hline 9 & Lowe's & 80.2 \\
\hline 10 & USAA & 79.7 \\
\hline 11 & Moderna & 79.6 \\
\hline 12 & In-n-Out Burger & 79.4 \\
\hline 13 & Unilever & 79.3 \\
\hline 14 & REI & 79.1 \\
\hline 15 & Paypal & 79.1 \\
\hline 16 & Subaru & 78.7 \\
\hline 17 & UPS & 78.7 \\
\hline 18 & Netflix & 78.4 \\
\hline 19 & Publix Supermarkets & 78.2 \\
\hline 20 & Toyota Motor Corporation & 78.1 \\
\hline 21 & Berkshire Hathaway & 78 \\
\hline 22 & The Kroger Company & 78 \\
\hline 23 & Dollar Tree & 78 \\
\hline 24 & Wegmans & 77.8 \\
\hline 25 & HP, Inc. & 77.5 \\
\hline
\end{tabular}

Source Data: The Harris Poll, 2021 Axios Harris Poll 100.

Table 5: The Least Trusted Companies in America for 2021

\begin{tabular}{|l|l|l|}
\hline Rank & Company & Trust Score (Index=100) \\
\hline 100 & Facebook & 53.8 \\
\hline 99 & The Trump Organization & 55 \\
\hline 98 & Fox Corporation & 55.6 \\
\hline 97 & TikTok & 60.3 \\
\hline 96 & Comcast & 61.5 \\
\hline 95 & Huawei Technologies & 62.1 \\
\hline 94 & Twitter & 62.2 \\
\hline 93 & Wells Fargo \& Company & 62.6 \\
\hline 92 & Wish.com & 63.1 \\
\hline 91 & Sears Holdings Corporation & 63.4 \\
\hline 90 & My Pillow & 65.5 \\
\hline 89 & BP & 65.9 \\
\hline 88 & AT\&T & 66.5 \\
\hline 87 & Uber & 66.8 \\
\hline 86 & Robinhood & 67.4 \\
\hline 85 & ExxonMobil & 67.5 \\
\hline
\end{tabular}


International Journal of Managing Public Sector Information and Communication Technologies (IJMPICT) Vol. 12, No.3, September 2021

\begin{tabular}{|l|l|l|}
\hline 84 & Reddit & 67.8 \\
\hline 83 & United Airlines & 68.4 \\
\hline 82 & Johnson \& Johnson & 68.8 \\
\hline 81 & Chipotle & 69.3 \\
\hline 80 & Bank of America & 69.7 \\
\hline 79 & Google & 70 \\
\hline 78 & JCPenney & 70.2 \\
\hline 77 & Nike & 70.3 \\
\hline 76 & Delta Air Lines & 70.4 \\
\hline
\end{tabular}

Source Data: The Harris Poll, 2021 Axios Harris Poll 100.

\subsection{Dimension 2: Ethics}

For the ethics dimension of corporate reputation, the survey participants were asked "Does this company maintain high ethical standards? 'Table 6 (The Most Ethical Companies in America for 2021) shows the companies regarded by Americans as being most regarded for their ethics. On the other end of the spectrum, Table 7 (The Least Ethical Companies in America for 2021) lists the firms that were judged by Americans to have the lowest ethical standing. The findings from the Axios/Harris Poll survey data reveal that Americans believe that the 3 most ethical companies today are Patagonia, Chick-fil-A, and Chewy. Conversely, survey participants rated The Trump Organization, Facebook, and Wish.com as the 3 firms having the lowest ethical standards today.

Table 6: The Most Ethical Companies in America for 2021

\begin{tabular}{|l|l|l|}
\hline Rank & Company & Ethics Score (Index=100) \\
\hline 1 & Patagonia & 84.7 \\
\hline 2 & Chick-fil-A & 82.5 \\
\hline 3 & Chewy & 82.4 \\
\hline 4 & Moderna & 81.6 \\
\hline 5 & Honda Motor Company & 81.3 \\
\hline 6 & Subaru & 81.2 \\
\hline 7 & USAA & 81.1 \\
\hline 8 & Wegmans & 80.7 \\
\hline 9 & REI & 80.4 \\
\hline 10 & Costco & 80.1 \\
\hline 11 & In-n-Out Burger & 79.8 \\
\hline 12 & PepsiCo & 79.6 \\
\hline 13 & IKEA & 79.3 \\
\hline 14 & Toyota Motor Corporation & 79.2 \\
\hline 15 & FedEx Corporation & 79.1 \\
\hline 16 & Paypal & 79 \\
\hline 17 & The Kroger Company & 78.9 \\
\hline & & \\
\hline
\end{tabular}


International Journal of Managing Public Sector Information and Communication Technologies (IJMPICT) Vol. 12, No.3, September 2021

\begin{tabular}{|l|l|l|}
\hline 18 & CVS (CVS Health) & 78.7 \\
\hline 19 & Lowe's & 78.5 \\
\hline 20 & Procter \& Gamble Co. & 78.2 \\
\hline 21 & Pfizer & 77.4 \\
\hline 22 & Hulu & 77.4 \\
\hline 23 & UPS & 77.3 \\
\hline 24 & Wayfair & 77.2 \\
\hline 25 & Publix Supermarkets & 77.1 \\
\hline
\end{tabular}

Source Data: The Harris Poll, 2021 Axios Harris Poll 100.

Table 7: The Least Ethical Companies in America for 2021

\begin{tabular}{|l|l|l|}
\hline Rank & Company & Ethics Score (Index=100) \\
\hline 100 & The Trump Organization & 55.2 \\
\hline 99 & Facebook & 55.9 \\
\hline 98 & Wish.com & 56.8 \\
\hline 97 & Fox Corporation & 57 \\
\hline 96 & TikTok & 62 \\
\hline 95 & Wells Fargo \& Company & 62 \\
\hline 94 & Comcast & 62.3 \\
\hline 93 & Twitter & 63 \\
\hline 92 & Huawei Technologies & 64.1 \\
\hline 91 & My Pillow & 65.2 \\
\hline 90 & Sears Holdings Corporation & 65.2 \\
\hline 89 & BP & 66.8 \\
\hline 88 & Google & 66.9 \\
\hline 87 & Uber & 66.9 \\
\hline 86 & Robinhood & 67.5 \\
\hline 85 & AT\&T & 67.5 \\
\hline 84 & United Airlines & 67.5 \\
\hline 83 & Walmart & 67.6 \\
\hline 82 & Reddit & 68.6 \\
\hline 81 & Dollar Tree & 69 \\
\hline 80 & Delta Air Lines & 69.9 \\
\hline 79 & Samsung & 70.1 \\
\hline 78 & ExxonMobil & 70.1 \\
\hline 77 & eBay & 70.4 \\
\hline 76 & Chipotle & 70.6 \\
\hline
\end{tabular}

Source Data: The Harris Poll, 2021 Axios Harris Poll 100. 
International Journal of Managing Public Sector Information and Communication Technologies (IJMPICT)

\subsection{Dimension 3: Citizenship}

Vol. 12, No.3, September 2021

For the citizenship dimension, the survey participants were asked "Does this company share my values and support good causes?" Table 8 (The Companies with the Best Citizenship in America for 2021) shows the results of the rankings of the best rated firms on this aspect of corporate reputation. On the reverse end of the citizenship equation, Table 9 (The Companies with the Worst Citizenship in America for 2021) reveals the companies rated worst in this regard. As can be seen in the two tables, survey participants rated Patagonia, Chewy, and USAA as being the 3 firms that best aligned with their values and supported the causes they believed in today. To the contrary, The Trump Organization, Facebook, and the Fox Corporation were rated as the 3 worst companies in terms of corporate citizenship.

Table 8: The Companies with the Best Citizenship in America for 2021

\begin{tabular}{|l|l|l|}
\hline Rank & Company & Citizenship Score (Index=100) \\
\hline 1 & Patagonia & 82 \\
\hline 2 & Chewy & 79.3 \\
\hline 3 & USAA & 78.9 \\
\hline 4 & Moderna & 78.7 \\
\hline 5 & Costco & 78 \\
\hline 6 & Chick-fil-A & 77.9 \\
\hline 7 & Unilever & 77.6 \\
\hline 8 & Pfizer & 77.3 \\
\hline 9 & Subaru & 77.3 \\
\hline 10 & Wegmans & 77.1 \\
\hline 11 & CVS (CVS Health) & 76.7 \\
\hline 12 & REI & 76.3 \\
\hline 13 & Hulu & 75.9 \\
\hline 14 & In-n-Out Burger & 75.8 \\
\hline 15 & Honda Motor Company & 75.7 \\
\hline 16 & 3 M Company & 75.4 \\
\hline 17 & SpaceX & 75.3 \\
\hline 18 & Berkshire Hathaway & 74.8 \\
\hline 19 & UPS & 74.7 \\
\hline 20 & Lowe's & 74.7 \\
\hline 21 & Publix Supermarkets & 74.6 \\
\hline 22 & Target & 74.5 \\
\hline 23 & PepsiCo & 74.4 \\
\hline 24 & The Kroger Company & 74.2 \\
\hline 25 & Walgreens & 74.2 \\
\hline & & \\
\hline
\end{tabular}

Source Data: The Harris Poll, 2021 Axios Harris Poll 100. 
International Journal of Managing Public Sector Information and Communication Technologies (IJMPICT) Vol. 12, No.3, September 2021

Table 9: The Companies with the Worst Citizenship in America for 2021

\begin{tabular}{|l|l|l|}
\hline Rank & Company & Citizenship Score (Index=100) \\
\hline 100 & The Trump Organization & 54.7 \\
\hline 99 & Facebook & 55.1 \\
\hline 98 & Fox Corporation & 57.7 \\
\hline 97 & Comcast & 59.4 \\
\hline 96 & Wish.com & 59.4 \\
\hline 95 & Wells Fargo \& Company & 60.5 \\
\hline 94 & TikTok & 60.6 \\
\hline 93 & Twitter & 60.9 \\
\hline 92 & Huawei Technologies & 61.2 \\
\hline 91 & AT\&T & 61.4 \\
\hline 90 & BP & 62.3 \\
\hline 89 & United Airlines & 63.9 \\
\hline 88 & Sears Holdings Corporation & 64.1 \\
\hline 87 & Uber & 64.2 \\
\hline 86 & My Pillow & 64.3 \\
\hline 85 & ExxonMobil & 64.4 \\
\hline 84 & Starbucks Corporation & 65.6 \\
\hline 83 & Yum! Brands & 65.9 \\
\hline 82 & JCPenney & 66.2 \\
\hline 81 & Delta Air Lines & 66.5 \\
\hline 80 & Walmart & 66.9 \\
\hline 79 & Google & 67 \\
\hline 78 & Samsung & 67.2 \\
\hline 77 & Robinhood & 67.3 \\
\hline 76 & GameStop & \\
\hline
\end{tabular}

Source Data: The Harris Poll, 2021 Axios Harris Poll 100.

\subsection{Dimension 4: Culture}

For the culture dimension, the survey participants were asked "Is this a good company to work for?"

Table 10 (The Best Companies to Work For in America for 2021) shows the ranking of the 100 most visible companies in terms of the firms Americans would most want to work for, while Table 11 (The Worst Companies to Work For in America for 2021) shows the lowest 10 rated companies in this regard. The results shown in these two tables reveal that Americans regarded Patagonia, Chick-fil-A, and Costco as being the 3 best companies to work for today, while rating The Trump Organization, Sears Holdings Corporation, and Wish.com as the 3 firms for whom they would least like to work. 
International Journal of Managing Public Sector Information and Communication Technologies (IJMPICT)

Vol. 12, No.3, September 2021

Table 10: The Best Companies to Work For in America for 2021

\begin{tabular}{|l|l|l|}
\hline Rank & Company & Culture Score (Index=100) \\
\hline 1 & Patagonia & 82.5 \\
\hline 2 & Chick-fil-A & 82.3 \\
\hline 3 & Costco & 81.8 \\
\hline 4 & PepsiCo & 81.7 \\
\hline 5 & Honda Motor Company & 81.6 \\
\hline 6 & Subaru & 81.6 \\
\hline 7 & Chewy & 81.2 \\
\hline 8 & UPS & 81.1 \\
\hline 9 & USAA & 81 \\
\hline 10 & Publix Supermarkets & 81 \\
\hline 11 & REI & 80.9 \\
\hline 12 & SpaceX & 80.8 \\
\hline 13 & Pfizer & 80.7 \\
\hline 14 & Berkshire Hathaway & 80.7 \\
\hline 15 & Apple & 80.3 \\
\hline 16 & Unilever & 80.1 \\
\hline 17 & Wegmans & 79.9 \\
\hline 18 & Toyota Motor Corporation & 79.8 \\
\hline 19 & Nestle & 79.8 \\
\hline 20 & FedEx Corporation & 79.6 \\
\hline 21 & Moderna & 79.5 \\
\hline 22 & Tesla Motors & 79.4 \\
\hline 23 & IKEA & 79.4 \\
\hline 24 & Hulu & 79.4 \\
\hline 25 & HP, Inc. & 79.2 \\
\hline
\end{tabular}

Source Data: The Harris Poll, 2021 Axios Harris Poll 100.

Table 11: The Worst Companies to Work For in America for 2021

\begin{tabular}{|l|l|l|}
\hline Rank & Company & Culture Scoreb(Index=100) \\
\hline 100 & The Trump Organization & 55.2 \\
\hline 99 & Sears Holdings Corporation & 58.2 \\
\hline 98 & Wish.com & 59.8 \\
\hline 97 & Fox Corporation & 60.1 \\
\hline 96 & Facebook & 60.4 \\
\hline 95 & Twitter & 63.6 \\
\hline 94 & Wells Fargo \& Company & 63.6 \\
\hline
\end{tabular}


International Journal of Managing Public Sector Information and Communication Technologies (IJMPICT) Vol. 12, No.3, September 2021

\begin{tabular}{|l|l|l|}
\hline 93 & TikTok & 64.3 \\
\hline 92 & Walmart & 64.5 \\
\hline 91 & Comcast & 65.2 \\
\hline 90 & JCPenney & 65.3 \\
\hline 89 & Uber & 66.4 \\
\hline 88 & My Pillow & 66.9 \\
\hline 87 & Huawei Technologies & 67.2 \\
\hline 86 & Burger King & 67.5 \\
\hline 85 & Dollar Tree & 68.6 \\
\hline 84 & United Airlines & 68.9 \\
\hline 83 & McDonald's & 69.1 \\
\hline 82 & Domino's Pizza & 69.8 \\
\hline 81 & AT\&T & 69.8 \\
\hline 80 & Yum! Brands & 70.2 \\
\hline 79 & BP & 70.4 \\
\hline 78 & Delta Air Lines & 70.6 \\
\hline 77 & Chipotle & 70.7 \\
\hline 76 & GameStop & 70.7 \\
\hline
\end{tabular}

Source Data: The Harris Poll, 2021 Axios Harris Poll 100.

\subsection{Dimension 5: Products and Services}

For the products and services dimension, the survey participants were asked "Does this company develop innovative products and services that I want and value?" The firms that Americans believed have the best products and services today are listed in Table 12 (The Companies with the Best Products and Services in America for 2021). At the other end of the spectrum, Table 13 (The Companies with the Worst Products and Services in America for 2021) shows the lowest 10 regarded firms among the 100 most visible companies today on the basis of their products and services. The survey results show that Americans perceived the 3 firms with the most desirable products and services on the market today to be the Honda Motor Company, Patagonia, and Pfizer. On the other hand, The Trump Organization, the Fox Corporation, and Wish.com were the 3 lowest rated firms in this regard.

Table 12: The Companies with the Best Products and Services in America for 2021

\begin{tabular}{|l|l|l|}
\hline Rank & Company & Products/Services Score $($ Index=100) \\
\hline 1 & Honda Motor Company & 85.5 \\
\hline 2 & Patagonia & 85.4 \\
\hline 3 & Pfizer & 85 \\
\hline 4 & SpaceX & 84.9 \\
\hline 5 & Tesla Motors & 84.9 \\
\hline 6 & Apple & 84.8 \\
\hline 7 & Moderna & 84.6 \\
\hline
\end{tabular}


International Journal of Managing Public Sector Information and Communication Technologies (IJMPICT) Vol. 12, No.3, September 2021

\begin{tabular}{|l|l|l|}
\hline 8 & Chewy & 84.6 \\
\hline 9 & Amazon.com & 84 \\
\hline 10 & REI & 83.6 \\
\hline 11 & Chick-fil-A & 82.5 \\
\hline 12 & HP, Inc. & 82.5 \\
\hline 13 & Procter \& Gamble Co. & 82.2 \\
\hline 14 & Microsoft & 82.1 \\
\hline 15 & 3 M Company & 82 \\
\hline 16 & Sony & 81.9 \\
\hline 17 & Royal Dutch Shell & 81.9 \\
\hline 18 & Costco & 81.8 \\
\hline 19 & Subaru & 81.8 \\
\hline 20 & Unilever & 81.8 \\
\hline 21 & Toyota Motor Corporation & 81.7 \\
\hline 22 & The Walt Disney Company & 81.6 \\
\hline 23 & PepsiCo & 81.3 \\
\hline 24 & CVS (CVS Health) & 80.8 \\
\hline 25 & Nestle & 80.8 \\
\hline & & \\
\hline
\end{tabular}

Source Data: The Harris Poll, 2021 Axios Harris Poll 100.

Table 13: The Companies with the Worst Products and Services in America for 2021

\begin{tabular}{|l|l|l|}
\hline Rank & Company & Products/Services Score (Index=100) \\
\hline 100 & The Trump Organization & 58.2 \\
\hline 99 & Fox Corporation & 60.1 \\
\hline 98 & Wish.com & 61.1 \\
\hline 97 & Sears Holdings Corporation & 64.9 \\
\hline 96 & Facebook & 64.9 \\
\hline 95 & Twitter & 65.4 \\
\hline 94 & Wells Fargo \& Company & 65.9 \\
\hline 93 & Dollar Tree & 67 \\
\hline 92 & TikTok & 67.1 \\
\hline 91 & Dollar General & 68.4 \\
\hline 90 & JCPenney & 68.4 \\
\hline 89 & United Airlines & 69 \\
\hline 88 & Uber & 69.2 \\
\hline 87 & Walmart & 70.1 \\
\hline 86 & My Pillow & 70.1 \\
\hline 85 & McDonald's & 70.3 \\
\hline 84 & AT\&T & 70.3 \\
\hline
\end{tabular}


International Journal of Managing Public Sector Information and Communication Technologies (IJMPICT) Vol. 12, No.3, September 2021

\begin{tabular}{|l|l|l|}
\hline 83 & Comcast & 70.4 \\
\hline 82 & Burger King & 70.7 \\
\hline 81 & Reddit & 71.4 \\
\hline 80 & BP & 71.4 \\
\hline 79 & Delta Air Lines & 72.2 \\
\hline 78 & Bank of America & 72.5 \\
\hline 77 & Fiat Chrysler Automobiles & 72.9 \\
\hline 76 & eBay & 73 \\
\hline
\end{tabular}

Source Data: The Harris Poll, 2021 Axios Harris Poll 100.

\subsection{Dimension 6: Vision}

For the vision dimension, the survey participants were asked "Does this company have a clear vision for the future?" The top ranked firms for vision in the most visible companies list are shown in Table 14 (The Companies with the Best Vision in America for 2021), while the lowest ranked corporations are listed in Table 15 (The Companies with the Worst Vision in America for 2021). As shown in the tables, Americans perceived SpaceX, Tesla Motors, and Amazon.com to be the companies having the "best" vision in 2021. Conversely, the participants in this national survey rated the Sears Holdings Corporation, The Trump Organization, and the Fox Corporation as displaying the "worst" vision today.

Table 14: The Companies with the Best Vision in America for 2021

\begin{tabular}{|l|l|l|}
\hline Rank & Company & Vision Score (Index=100) \\
\hline 1 & SpaceX & 86.5 \\
\hline 2 & Tesla Motors & 85.7 \\
\hline 3 & Amazon.com & 84.5 \\
\hline 4 & PepsiCo & 84.3 \\
\hline 5 & Pfizer & 83.7 \\
\hline 6 & Honda Motor Company & 83.3 \\
\hline 7 & Nestle & 83.1 \\
\hline 8 & Patagonia & 82.9 \\
\hline 9 & Moderna & 82.8 \\
\hline 10 & USAA & 82.5 \\
\hline 11 & Chewy & 82.4 \\
\hline 12 & Toyota Motor Corporation & 82.4 \\
\hline 13 & The Walt Disney Company & 82.4 \\
\hline 14 & Subaru & 82.3 \\
\hline 15 & Costco & 81.8 \\
\hline 16 & Apple & 81.5 \\
\hline 17 & Chick-fil-A & 81.4 \\
\hline 18 & Paypal & 81.4 \\
\hline & & \\
\hline
\end{tabular}


International Journal of Managing Public Sector Information and Communication Technologies (IJMPICT) Vol. 12, No.3, September 2021

\begin{tabular}{|l|l|l|}
\hline 19 & Wegmans & 81.1 \\
\hline 20 & FedEx Corporation & 81 \\
\hline 21 & Berkshire Hathaway & 80.9 \\
\hline 22 & Unilever & 80.8 \\
\hline 23 & IKEA & 80.7 \\
\hline 24 & CVS (CVS Health) & 80.7 \\
\hline 25 & In-n-Out Burger & 80.5 \\
\hline
\end{tabular}

Source Data: The Harris Poll, 2021 Axios Harris Poll 100.

Table 15: The Companies with the Worst Vision in America for 2021

\begin{tabular}{|l|l|l|}
\hline Rank & Company & Vision Score (Index=100) \\
\hline 100 & Sears Holdings Corporation & 57.6 \\
\hline 99 & The Trump Organization & 63 \\
\hline 98 & Fox Corporation & 63.3 \\
\hline 97 & JCPenney & 65.1 \\
\hline 96 & Facebook & 65.2 \\
\hline 95 & Wish.com & 65.5 \\
\hline 94 & Comcast & 66.9 \\
\hline 93 & Twitter & 67.1 \\
\hline 92 & Wells Fargo \& Company & 67.5 \\
\hline 91 & My Pillow & 68.3 \\
\hline 90 & Reddit & 69.2 \\
\hline 89 & TikTok & 69.6 \\
\hline 88 & GameStop & 69.8 \\
\hline 87 & United Airlines & 70 \\
\hline 86 & AT\&T & 70.1 \\
\hline 85 & Fiat Chrysler Automobiles & 71.5 \\
\hline 84 & Huawei Technologies & 72.1 \\
\hline 83 & The Coca-Cola Company & 72.2 \\
\hline 82 & BP & 72.3 \\
\hline 81 & Burger King & 72.4 \\
\hline 80 & Uber & 72.4 \\
\hline 79 & Macy's & 72.5 \\
\hline 78 & Chipotle & 72.5 \\
\hline 77 & ExxonMobil & 73 \\
\hline 76 & Samsung & 73.9 \\
\hline & & \\
\hline
\end{tabular}

Source Data: The Harris Poll, 2021 Axios Harris Poll 100. 
International Journal of Managing Public Sector Information and Communication Technologies (IJMPICT)

\subsection{Dimension 7: Growth}

For the growth dimension, the survey participants were asked "Is this a growing company?" The survey findings regarding the top rated firms in regards to their growth possibilities are shown in Table 16 (The Companies with the Best Growth Prospects in America for 2021). At the other end of the growth equation, the lowest ranked firms are listed in Table 17 (The Companies with the Worst Growth Prospects in America for 2021). For this last aspect of corporate reputation, survey respondents judged Amazon.com, SpaceX, and Pfizer as having the highest potential for growth today. On the reverse side of the growth equation, Americans held that the Sears Holdings Corporation, The Trump Organization, and the Fox Corporation currently had the worst growth prospects.

Table 16: The Companies with the Best Growth Prospects in America for 2021

\begin{tabular}{|l|l|l|}
\hline Rank & Company & Growth Score (Index=100) \\
\hline 1 & Amazon.com & 86.5 \\
\hline 2 & SpaceX & 86 \\
\hline 3 & Pfizer & 85.8 \\
\hline 4 & Chewy & 84.9 \\
\hline 5 & Chick-fil-A & 84.8 \\
\hline 6 & Moderna & 84.4 \\
\hline 7 & Tesla Motors & 84.4 \\
\hline 8 & Apple & 84.1 \\
\hline 9 & Patagonia & 83.4 \\
\hline 10 & Subaru & 83.2 \\
\hline 11 & Honda Motor Company & 83.1 \\
\hline 12 & USAA & 82.9 \\
\hline 13 & Hulu & 82.4 \\
\hline 14 & PepsiCo & 82.1 \\
\hline 15 & In-n-Out Burger & 82 \\
\hline 16 & IKEA & 81.9 \\
\hline 17 & CVS (CVS Health) & 81.9 \\
\hline 18 & FedEx Corporation & 81.8 \\
\hline 19 & Costco & 81.6 \\
\hline 20 & Unilever & 81.4 \\
\hline 21 & Publix Supermarkets & 81.3 \\
\hline 22 & Berkshire Hathaway & 81 \\
\hline 23 & Nestle & 81 \\
\hline 24 & Wegmans & 80.9 \\
\hline 25 & The Walt Disney Company & 80.7 \\
\hline & & \\
\hline
\end{tabular}

Source Data: The Harris Poll, 2021 Axios Harris Poll 100. 
International Journal of Managing Public Sector Information and Communication Technologies (IJMPICT) Vol. 12, No.3, September 2021

Table 17: The Companies with the Worst Growth Prospects in America for 2021

\begin{tabular}{|l|l|l|}
\hline Rank & Company & Growth Score (Index=100) \\
\hline 100 & Sears Holdings Corporation & 54.1 \\
\hline 99 & The Trump Organization & 57.8 \\
\hline 98 & Fox Corporation & 60.2 \\
\hline 97 & JCPenney & 60.7 \\
\hline 96 & My Pillow & 63.4 \\
\hline 95 & Facebook & 63.9 \\
\hline 94 & Wish.com & 65.3 \\
\hline 93 & Wells Fargo \& Company & 67 \\
\hline 92 & Twitter & 67.2 \\
\hline 91 & Macy's & 68.3 \\
\hline 90 & AT\&T & 68.5 \\
\hline 89 & United Airlines & 68.8 \\
\hline 88 & GameStop & 69.4 \\
\hline 87 & Huawei Technologies & 69.5 \\
\hline 86 & TikTok & 70.2 \\
\hline 85 & Comcast & 70.6 \\
\hline 84 & Delta Air Lines & 71.4 \\
\hline 83 & Nordstrom & 72.1 \\
\hline 82 & Samsung & 72.6 \\
\hline 81 & Burger King & 72.6 \\
\hline 80 & Reddit & 72.8 \\
\hline 79 & BP & 72.8 \\
\hline 78 & Fiat Chrysler Automobiles & 73.4 \\
\hline 77 & General Motors & 73.5 \\
\hline 76 & Goya & 73.6 \\
\hline
\end{tabular}

Source Data: The Harris Poll, 2021 Axios Harris Poll 100.

\subsection{Analysis}

It is important to note one thing regarding the public's perception of companies today. There is definitely more variance to be found among the companies that are, overall, well-perceived by the American public today than those that are poorly perceived. One could indeed argue that the public today has a more powerful "horns effect" [19], meaning that they rate companies they dislike poorly across the board on all dimensions of corporate reputation, than is the "halo effect" [20]. Companies such as the Trump Organization, Facebook, Sears, etc. tend to be negatively perceived no matter what the specific issue may be by the public today, and this strong negative perception may be very, very difficult to overcome, even in time, due to the strength of the public's feelings in regard to these firms. On the flip side, companies that were held in high standing by Americans overall, such as Patagonia, Chewy, Chick-fil-A, etc, performed well 
across the board, even perhaps in categories where they might not actually deserve to be ranked highly, based on their overall image and the positive perception of it by consumers.

Take for instance the trust dimension of corporate reputation. As can be seen in Table 4 (The Most Trusted Companies in America for 2021), the fast-growing pet company, Chewy, was found to be the most trusted company in America in 2021, followed closely by the highly-regarded fastfood giant, Chick-fil-A. Patagonia, the top-rated company in terms of its overall RQ Score, was rated third by consumers in terms of trustworthiness, followed by Costco and the Honda Motor Company.

On the flip-side of the trust dimension, companies that were in the news - for the wrong reasons fared poorly in the Axios/Harris Poll national survey. As can be seen in Table 5 (The Least Trusted Companies in America for 2021), Facebook was rated as the least trustworthy company in America in 2021. With the company being in the news both over data privacy concerns [21] and for the use of its platform for misinformation in regards to the 2020 election [22] and COVID-19 [23], this should come as no surprise. The influence of the 2020 election controversies [24] was also seen in this ranking on least trusted firms as former President Trump's company (The Trump Organization) was ranked 99th and Fox Corporation (the parent of Fox News) was ranked 98th. Further, My Pillow, headed by Mike Lindell, who has been highly vocal - and visible - in defending the allegations of voter fraud made by former President Trump [25], also found itself among the least trusted companies by Americans in 2021.

These findings were found across all 7 of the aspects that make-up corporate reputation. As such, it shows that Americans today are very likely to paint companies and their brands with a "broad brush," holding them in alternatively high or low regard based on likely one particular "thing" that they like or dislike, agree or disagree with, etc. about the company and/or its leadership. We can see this negatively with companies headed by Former President Donald Trump and his advocate Mike Lindell. We can also see this with mixed findings regarding firms headed by visionary tech entrepreneurs like Jeff Bezos (Amazon), Mark Zuckerberg (Facebook), and Elon Musk (SpaceX and Tesla Motors). Certainly, this aspect of consumer perception deserves more attention from both corporate management and researchers due to the demonstrated strength - and consistency - of consumer perceptions today among the American public.

Overall, the findings on the 7 dimensions of corporate reputation presented here highlight just how important this complex and dynamic construct is for companies today. In the concluding discussion to follow, we look at what this means for both management in practice and for managerial and marketing research moving forward.

\section{Conclusions}

We began this article with the quote: "Image is everything." The findings of this study certainly reinforce this notion when it comes to companies and their brands today. The notion of brand value is more important now than ever before. Indeed, a recent study showed that the top 100 global brands grew over 40\% in value in 2020 alone, with Amazon's brand value assessed to be approaching $\$ 700$ billion dollars [26]! And so the whole notion of managing the public image of a company and its brands is one of the more significant tasks for management today. However, this is not just the concern of major consumer brands, as for all businesses, large and small alike, the whole notion of managing - and monitoring - public perception of the company, its leaders, its brands, and its reputation on multiple dimensions, should - and must - be a top managerial priority today. We will thus conclude this article by discussing the implications of this study for both management in practice and for research. 


\subsection{Implications for Management}

Vol. 12, No.3, September 2021

The findings of the present research demonstrate just how important a task managing a company's reputation is today for management. With the "24/7" news cycle and the fact that social media is "always on," companies today have more opportunities than ever to see their reputations - and the value of those reputations - to be more at risk than ever before. As such, from the executive suite through the ranks of management and down to the front lines, company management needs to be focused on doing the "right things" to help build up their reputations and to avoid doing the "wrong things." This will take building a mindset throughout the company to have everyone - from the C-suite to those dealing directly with customers, to be both vigilant for potential "things" that could harm the company's reputation to alternatively, opportunities to help build up the reputation of the company and its brands. This will also take constant efforts to reinforce just how important every interaction with customers, constituents, members of the media, etc. is in today's environment. Companies must thus be proactive in consciously managing their reputations and proactive in working - in small ways and in large ones as well - to build better reputations to enhance their image and their brand(s) in the minds of the public. Firms that do so well can greatly enhance their standing in an ever-more competitive consumer marketplace; firms that do not will carry an enhanced "reputational risk" that today can be nothing less than catastrophic, as evidence by the negative trajectories of companies such as The Trump Organization, the Fox Corporation, My Pillow and more.

\subsection{Directions for Future Research}

The present study certainly lays the groundwork for deeper investigation into the whole notion of corporate reputation and the relationship between a company's visibility and its reputation. Certainly, with the wealth of data available from the 20+years that The Harris Poll has conducted its annual survey on corporate reputations among America's leading companies, it will be interesting to see how firms' reputations - both overall and on each of the 7 dimensions of reputation - change over time. Thus, longitudinal research on this data set is a next logical step. This could lead to not just investigations on how the reputation of companies, and indeed, entire industries, change in the minds of consumers over time, but even more importantly, what the relationships might be between reputational change and corporate performance. By delving into how reputational changes over the years might be related - both positively and negatively - to outcome metrics such as firm profitability, revenue, stock price and market valuation, etc., such studies could enhance our understanding of the relationships between corporate/brand image and firm performance.

Future work in this area should also delve into the whole notion of what exactly are the components of a company's reputation and how they interrelate. As noted previously, consumer perceptions of corporate reputation seem to be very broad in nature. It would be interesting to conduct further research into just why this is the case and how elastic - or inelastic - such views may be over time. And while there is certainly the need to more closely examine the relationship between the 7 prescribed components of corporate reputation used in the Axios/Harris Poll research, future research should look at how this construct might be further refined and perhaps, either expanded into more dimensions or compressed into fewer aspects. Either approach - and outcome - would provide not just the basis for enhanced research into corporate reputation, but when translated into management practice, would enable executives to focus on what truly matters in terms of company and brand image in the minds of consumers today. And while to date all of this research has been focused on the United States, there is really no reason that future research could not use these same approaches and models to look at corporate reputations either 
International Journal of Managing Public Sector Information and Communication Technologies (IJMPICT) Vol. 12, No.3, September 2021

regionally (i.e. Europe, Asia, etc.) or internationally, especially in a time where we think of global brands and branding more and more.

\section{REFERENCES}

[1] Tignor, Steve (2015). “1989: Image is Everything - Andre Agassi’s Infamous Ad,” Tennis Magazine, August 13, 2015. Available: https://www.tennis.com/news/articles/1989-image-is-everything-andreagassi-s-infamous-ad.

[2] Van Praet, Douglas (2015). "Why Image Is Everything: Recent Research Reveals That Image and Emotion Beat Fact and Logic," Psychology Today, August 17, 2015. Available: https://www.psychologytoday.com/us/blog/unconscious-branding/201508/why-image-is-everything.

[3] Aquino, Judith \& Kim Bhasi (2011). "9 Reasons Why Your Image Is Everything," Insider, December 20, 2011. Available: https://www.businessinsider.com/why-your-image-is-everything-12-2011.

[4] Hirsh, Evan, Steve Hedlund \& Mark Schweizer (2003). "Reality Is Perception: The Truth about Car Brands." Strategy + Business, Fall 2003 (Issue 32). Available: https://www.strategybusiness.com/article/03302.

[5] Latson, Jennifer (2014). "How Poisoned Tylenol Became a Crisis-Management Teaching Model." Time, September 29, 2014. Available: https://time.com/3423136/tylenol-deaths-1982/.

[6] Khatchadourian, Raffi (2011). "The Gulf War: Were There Any Heroes in the BP Oil Disaster?" The New Yorker, March 6, 2011. Available: https://www.newyorker.com/magazine/2011/03/14/the-gulfwar.

[7] Pesce, Nicole Lyn (2021). "Calls to Boycott Toyota Fueled by Its Donations to Election-objector Republicans.” MarketWatch, June 28, 2021. Available: https://www.marketwatch.com/story/calls-toboycott-toyota-fueled-by-its-donations-to-election-objector-republicans-11624898975.

[8] Sickler, Jonas (2021). "What is Reputational Risk and How to Manage it." Reputation Management, January 5, 2021. Available: https://www.reputationmanagement.com/blog/reputational-risk/.

[9] Mandel, Eric (2019). "Chick-fil-A to 'Add Clarity' in 2020 to Nonprofit Giving." Atlanta Business $\begin{array}{llll}\text { Chronicle, } & \text { November } & 18, & 2019 .\end{array}$ https://www.bizjournals.com/atlanta/news/2019/11/18/chick-fil-a-to-add-clarity-in-2020-tononprofit.html.

[10] Harding, Carolyn (2020). "Major Brands Support Environmental Causes Through Latest Social Responsibility Campaigns." DMS Insights, August 20, 2020. Available: https://insights.digitalmediasolutions.com/articles/social-responsibility-campaigns.

[11] Lee, Jacqueline (2017). "Southwest Fills in 'Tiny Piece of Home' for Critically Ill Children, Families." The Mercury News, March 17, 2017. Available: https://www.mercurynews.com/2016/11/22/palo-alto-southwest-fills-in-tiny-piece-of-home-forcritically-ill-children-families/.

[12] Chandler, Krista (2016). "McDonald's Manager Knows Firsthand How Ronald McDonald Houses Help.” The Lompoc Record, November 15, 2016. Available: https://lompocrecord.com/mcdonaldsmanager-knows-firsthand-how-ronald-mcdonald-houses-help/article_c658e7ce-06e9-55fc-95c9460c240db7ee.html.

[13] ValueAdder (n.d.). "Business Goodwill." Available:https://www.valuadder.com/glossary/businessgoodwill.html.

[14] Giuliani, Marco and Daniel Brännström (October 2011). "Defining Goodwill: A Practice Perspective." Journal of Financial Reporting and Accounting, Vol. 9 No. 2, pp. 161-175. https://doi.org/10.1108/19852511111173112.

[15] The Harris Poll (May 2021). 2021 Axios Harris Poll 100. Available: https://theharrispoll.com/axiosharris-poll-100-release-2021/.

[16] The Harris Poll (May 2021). Corporate Reputation Rankings. Available: https://theharrispoll.com/axios-harrispoll-100/.

[17] Axios (May 13, 2021). "The 2021 Axios Harris Poll 100 Reputation Rankings." Available: https://www.axios.com/the-2021-axios-harris-poll-100-reputation-rankings-af44bec1-4e00-4af49952-7bf4caa06cd6.html. 
International Journal of Managing Public Sector Information and Communication Technologies (IJMPICT) Vol. 12, No.3, September 2021

[18] The Harris Poll (May 13, 2021). "Patagonia, Honda, Moderna, Chick-fil-A, SpaceX Top 'AxiosHarris Poll 100' With the Best Reputations." Available: https://theharrispoll.com/axios-harris-poll100-release-2021/.

[19] Sundar, Aparna, Frank Kardes, and Theodore Noseworthy (2014). "Inferences on Negative Labels and the Horns Effect", Advances in Consumer Research, Volume 42, eds. June Cotte and Stacy Wood, Duluth, MN: Association for Consumer Research, Pages: 377-380.

[20] Leuthesser, Lance, Kohli, Chiranjeev S. and Harich, Katrin R. (1995). "Brand Equity: The Halo Effect Measure", European Journal of Marketing, Vol. 29 No. 4, pp. 57-66. https://doi.org/10.1108/03090569510086657.

[21] Ngadaonye, Michael O. (2021). "Facebook And Data Privacy Issues.” The Circular, March 26, 2021. Available: https://thecircular.org/facebook-and-data-privacy-issues/.

[22] Rogers, Richard (2020). "Research Note: The Scale of Facebook's Problem Depends Upon How 'Fake News' is Classified.” Harvard Kennedy School Misinformation Review, October 26, 2020. Available: $\quad$ https://misinforeview.hks.harvard.edu/article/research-note-the-scale-of-facebooksproblem-depends-upon-how-fake-news-is-classified/.

[23] Aten, Jason (2021). "Facebook Wants to Be Judged By Its Best Intentions, Not Its Covid-19 Misinformation Problem." Inc., July 2021. Available: https:/www.inc.com/jason-aten/facebookwants-to-be-judged-by-its-best-intentions-not-its-covid-19-misinformation-problem.html.

[24] Kamarck, Elaine (2021). "Did Trump Damage American Democracy?” FixGov fromThe Brookings Institution, July 9, 2021. Available: https://www.brookings.edu/blog/fixgov/2021/07/09/did-trumpdamage-american-democracy/.

[25] Maheshwari, Sapna and Tiffany Hsu (2021). "MyPillow C.E.O.'s Trump Conspiracy Theories Put Company on the Spot." The New York Times, February 22, 2021. Available: https://www.nytimes.com/2021/01/27/business/mike-lindell-mypillow.html.

[26] MarketingCharts.com (2021). "Most Valuable Brands Enjoy Record Growth.” July 19, 2021. Available: https://www.marketingcharts.com/brand-related/top-brands-117704.

\section{AUTHOR}

David Wyld (dwyld@ selu.edu) serves as theMerritt Professor of Strategic Management at Southeastern Louisiana University in Hammond, Louisiana. Dr. Wyld is the founder and publisher of both Modern Business Press (publishing leading-edge academic journals) and The IDEA Publishing (publishing articles of interest across a wide variety of topics, giving both newbie authors and content marketers a platform for their ideas). As a prolific writer himself, he is a frequent contributor to both respected academic journals and widely read trade and general interest publications. He has established himself as one of the leading academic experts on emerging applications of technology

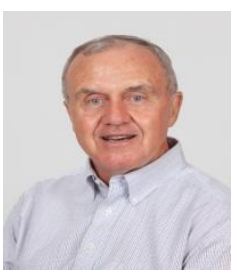
in both the private and public sectors. Dr. Wyld continues to be an active strategic management consultant, a qualified expert witness, and invited speaker on a wide variety of topics to trade, corporate, governmental, and academic audiences. He has made appearances on management and technology issues on The Discovery Channel, ESPN Radio, Federal News Radio, and other media outlets.

Dr. Wyld has earned Southeastern's President's Award for both Excellence in Teaching and Research, making him one of a select group of faculty who have been awarded campus-wide recognition for more than one aspect of the professorial role. He earned his doctorate from the University of Memphis in 1993. 